\title{
Sistem Informasi Penjualan Sembako Berbasis Website pada UD. Bintan Jaya
}

\author{
Wanhendra ${ }^{1}$, Kevin Perdana ${ }^{2}$, Heliyanto $^{3}$ \\ ${ }^{1}$ Jurusan Sistem Informasi Konsentrasi Komputer Akuntansi STT Indonesia Tanjungpinang \\ Jln. Pompa Air No. 28 Tanjungpinang Kepulauan Riau Indonesia \\ 'heliyanto2908@gmail.com \\ ${ }^{2,3}$ Sekolah Tinggi Teknologi Indonesia Tanjungpinang \\ Jln. Pompa Air No. 28 Tanjungpinang Kepulauan Riau Indonesia \\ ${ }^{2}$ wan.stti@gmail.com, ${ }^{3}$ kevin@sttindonesia.ac.id
}

\begin{abstract}
Intisari- Sistem informasi penjualan dewasa ini sangat diperlukan berbagai masyarakat di berbagai kalangan dikarenakan dapat membantu masyarakat dalam suatu pengambilan keputusan secara tepat melalui internet dan juga teknologi yang mulai pesat untuk saat ini. Hal ini juga dapat membantu khususnya dalam dunia bisnis supaya informasi yang di dapat lebih real-time. Didalam proses penjualan sembako sampai saat ini masih menggunakan sistem manual. Mulai dari input data penjualan, input data transaksi, sampai pembuatan laporan penjualan. Karena ada beberapa kekurangan dari sistem yang sudah ada, maka diharapkan adanya suatu sistem yang baru yang dapat mendukung dan memperbaiki sistem yang sudah ada, oleh karena itu perlu dicari alternatif dalam penanganan data tersebut. Dengan adanya sistem komputerisasi akan memberikan kita kemudahan dalam mengerjakan suatu pekerjaan untuk mendapatkan hasil yang lebih baik. Disinilah manfaat sistem komputerisasi dalam membantu memecahkan masalah secara efektif dan efisien. Sistem yang akan dibuat menggunakan bahasa pemrograman PHP, yang mana sistem ini digunakan oleh admin.
\end{abstract}

Kata Kunci : Sistem, Informasi, Penjualan, Barang, Website

Abstract-Today's sales information system is needed by various communities in various places because it can help people everywhere through the internet as well as technology that is starting to increase for now. This can help specifically in the business world requesting information that can be real-time. In the sales process until now still using a manual system. Starting from sales data input, input transaction data, to making sales reports. Because there are some disadvantages of the existing system, it is hoped that there will be a new system that can support and improve the existing system, therefore it is necessary to find alternatives in managing the data. With the existence of a computerized system will give us the ease of doing a job to get better results. This is where the benefits of computerized systems help solve problems that are effective and efficient. The system will be created using the PHP Programming language, which is used by the admin system.

Keywords: Systems, Information, Sales, Goods, Website

\section{Pendahuluan}

Sistem informasi penjualan dewasa ini sangat diperlukan berbagai masyarakat di berbagai kalangan dikarenakan dapat membantu masyarakat dalam suatu pengambilan keputusan secara tepat melalui internet dan juga teknologi yang mulai pesat untuk saat ini. Hal ini juga dapat membantu khususnya dalam dunia bisnis supaya informasi yang di dapat lebih realtime.

UD. Bintan Jaya masih menggunakan proses manual dalam sistem penjualannya. Dengan adanya sistem informasi penjualan yang akan dibangun dapat memudahkan semua para pekerja dalam hal transaksi yang lebih efisien, cepat dan fleksibel, pembuatan pengolahan data menjadi cepat, menguntungkan dari segi ekonomi dan membantu promosi lebih luas lagi jika sistem berbasis web ini berhasil dibuat dan dikembangkan. Selain itu pembeli juga tidak perlu harus datang jauh-jauh untuk memesan karena sudaha ada layanan online yang mendukung sistem penjualan dari UD. Bintan Jaya.

\section{Metodologi Penelitian}

Metodologi penelitian merupakan suatu proses yang digunakan untuk memecahkan suatu masalah secara logis, dimana memerlukan data-data untuk mendukung terlaksananya suatu penelitian. Metodologi ini akan dijelaskan dalam bentuk pengumpulan data dan metode pengembangan sistem. Dalam hal ini metode yang digunakan yaitu metode studi lapangan dengan melakukan survei langsung ke lokasi untuk mendapatkan informasi sesuai yang diperlukan. Serta mengacu pada metode Waterfall. Adapun tahapan yang dilakukan sebagai berikut :

a. Analisis kebutuhan perangkat lunak

Proses pengumpulan kebutuhan dilakukan secara intensif untuk mespesifikasikan kebutuhan perangkat lunak agar dapat dipahami perangkat lunak seperti apa yang dibutuhkan oleh user. Spesifikasi kebutuhan perangkat lunak pada tahap ini perlu untuk didokumentasikan. 
b. Desain

Desain perangkat lunak adalah proses multi langkah yang fokus pada desain pembuatan program perangkat lunak termasuk struktur data, arsitektur perangkat lunak, representasi antarmuka, dan prosedur pengodean. Tahap ini mentranslasi kebutuhan perangkat lunak dari tahap analisis kebutuhan ke representasi desain agar dapat diimplementasikan menjadi program pada tahap selanjutnya. Desain perangkat lunak yang dihasilkan pada tahap ini juga perlu didokumentasikan.

c. Pembuatan kode program

Desain harus ditranslasikan ke dalam program perangkat lunak. Hasil dari tahap ini adalah program komputer sesuai dengan desain yang telah dibuat pada tahap desain.

d. Pengujian

Pengujian fokus pada perangkat lunak secara segi lojik dan fungsional dan memastikan bahwa semua bagian sudah diuji. Hal ini dilakukan untuk meminimalisir kesalahan (error) dan memastikan keluaran yang dihasilkan sesuai dengan yang diinginkan.

e. Pendukung (support) atau pemeliharaan (maintenance) Tidak menutup kemungkinan sebuah perangkat lunak mengalami perubahan ketika sudah dikirimkan ke user. Perubahan bisa terjadi karena adanya kesalahan yang muncul dan tidak terdeteksi saat pengujian atau perangkat lunak harus beradaptasi dengan lingkungan baru. Tahap pendukung atau pemeliharaan dapat mengulangi proses pengembangan mulai dari tahap analisis spesifikasi untuk perubahan perangkat lunak baru

Selain menggunakan metode Waterfall dan survei, dalam pengumpulan data ini juga dilakukan menggunakan pendekatan melalui teori-teori serta referensi yang ada pada buku maupun internet sesuai kebutuhan. Adapun beberapa referensi dari buku maupun internet sebagai berikut :

1. Definisi Penjualan

Secara umum definisi penjualan dapat diartikan sebagai sebuah usaha atau langkah konkrit yang dilakukan untuk memindahkan suatu produk, baik itu berupa barang ataupun jasa, dari produsen kepada konsumen sebagai sasarannya.

Tujuan utama penjualan yaitu mendatangkan keuntungan atau laba dari produk ataupun barang yang dihasilkan produsennya dengan pengelolaan yang baik. Dalam pelaksanaannya, penjualan sendiri tak akan dapat dilakukan tanpa adanya pelaku yang bekerja didalamnya seperti agen, pedagang dan tenaga pemasaran

\section{Definisi Penjualan Online}

Penjualan online adalah melakukan aktivitas penjualan dari mencari calon pembeli sampai menawarkan produk atau barang dengan memanfaatkan jaringan internet yang didukung dengan seperangkat alat elektronik sebagai penghubung dengan jaringan internet. Penjualan online merupakan prosedur berdagang atau mekanisme jual-beli di internet dimana pembeli dan penjual dipertemukan di dunia maya.
Penjualan online juga dapat didefinisikan sebagai suatu cara berbelanja atau berdagang secara online atau direct selling yang memanfaatkan fasilitas internet dimana terdapat website yang dapat menyediakan layanan "get and deliver". Penjualan online akan merubah semua kegiatan marketing dan juga sekaligus memangkas biaya-biaya operasional untuk kegiatan trading (perdagangan).

Beberapa pengaruh dengan adanya penjualan online yaitu :

1. Kehadiran e-commerce yang terus berkembang lambat laun akan merubah kebiasaan bertransaksi sebagian masyarakat kita. Para produsen maupun konsumen akan terbiasa menjual maupun membeli produk dan jasa secara online ketimbang melangkahkan kaki ke outlet penjualan. Ruang dan waktu bukan lagi menjadi kendala. Sebuah perusahaan di Indonesia memiliki kesempatan yang sama dengan kalangan bisnis asing untuk menjalin kerjasama atau ingin mengakses pasar mancanegara.

2. Seseorang lebih mudah untuk mengembangkan usahanya seperti dengan menjual barang dan jasa via online. Banyak sekali situs yang menyediakan jual beli online. Salah satu yang terbesar adalah TokoBagus(dot)com. Dengan adanya internet pula kita tidak perlu repot pergi untuk membeli barang yang kita butuhkan.

3. Kemajuan teknologi akan meningkatkan kemampuan produktivitas dunia industri baik dari aspek teknologi industri maupun pada aspek jenis produksi. Investasi dan reinvestasi yang berlangsung secara besar-besaran yang akan semakin meningkatkan produktivitas dunia ekonomi. Di masa depan, dampak perkembangan teknologi di dunia industri akan semakin penting. Tanda-tanda telah menunjukkan bahwa akan segera muncul teknologi bisnis yang memungkinkan konsumen secara individual melakukan kontak langsung dengan pabrik sehingga pelayanan dapat dilaksanakan secara langsung dan selera individu dapat dipenuhi.

Beberapa proses dalam penjualan online adalah sebagai berikut :

1. Presentasi electronic (pembuatan website) untuk produk dan layanan.

2. Pemesanan secara langsung dan tersedianya tagihan.

3. Otomasi account pelanggan secara aman (baik nomor rekening maupun nomor kartu kredit).

4. Pembayaran yang dilakukan secara langsung (online) dan penanganan transaksi. Mengenal lawan komunikasi, maka jenis informasi yang dikirimkan dapat disusun sesuai dengan kebutuhan dan kepercayaan (trust).

5. Pertukaran data (data exchange) berlangsung berulang-ulang dan secara berkala, misalnya setiap hari, dengan format data yang sudah disepakati bersama. Dengan kata lain, service yang digunakan sudah tertentu. 
6. Salah satu pelaku dapat melakukan inisiatif untuk mengirimkan data, tidak harus menunggu parternya. Model yang umum digunakan adalah peer-to-peer, dimana processing intelligence dapat didistribusikan di kedua pelaku bisnis

\section{Unified Modeling Language (UML)}

Unified Modeling Language (UML) adalah suatu alat untuk memvisualisasikan dan mendokumentasikan hasil analisa dan desain yang berisi sintak dalam memodelkan sistem secara visual. Juga merupakan satu kumpulan konvensi pemodelan yang digunakan untuk menentukan atau menggambarkan sebuah sistem software yang terkait dengan objek.

Sejarah UML sendiri terbagi dalam dua fase; sebelum dan sesudah munculnya UML. Dalam fase sebelum, UML sebenarnya sudah mulai diperkenalkan sejak tahun 1990an namun notasi yang dikembangkan oleh para ahli analisis dan desain berbeda-beda, sehingga dapat dikatakan belum memiliki standarisasi.

Fase kedua; dilandasi dengan pemikiran untuk mempersatukan metode tersebut dan dimotori oleh Object Management Group (OMG) maka pengembangan UML dimulai pada akhir tahun 1994 ketika Grady Booch dengan metode OOD (ObjectOriented Design), Jim Rumbaugh dengan metode OMT (Object Modelling Technique) mereka ini bekerja pada Rasional Software Corporation dan Ivar Jacobson dengan metode OOSE (Object-Oriented Software Engineering) yang bekerja pada perusahaan Objectory Rasional.

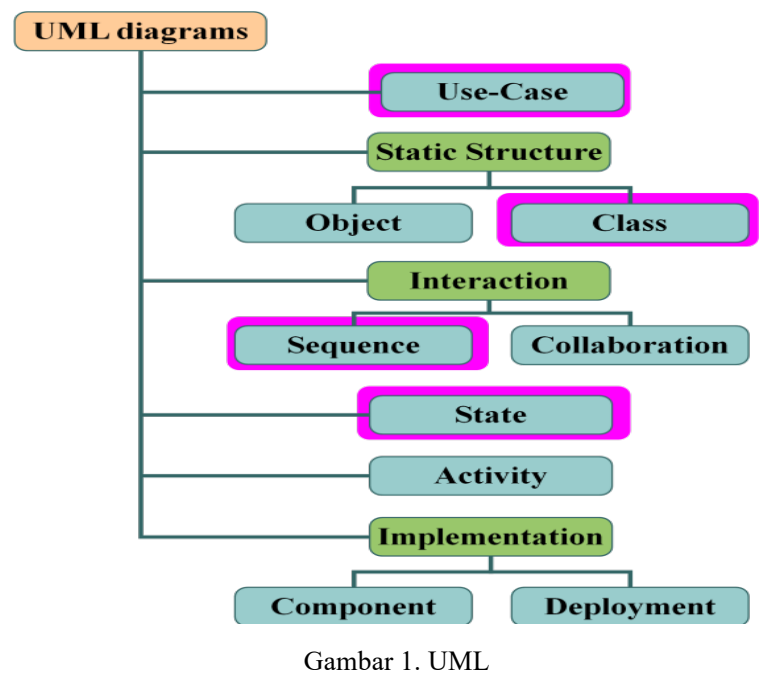

\section{HASIL DAN PEMBAHASAN}

Secara sederhana penyusunan sistem adalah bagaimana membangun suatu kombinasi dari input, proses dan output yang akan dihasilkan. Program input adalah bentuk tampilan interface yang dapat dilihat langsung sebagai mediasi admin untuk mencatat data penjualan, data transaksi, serta data pemesanan sembako. Kemudian admin juga harus membuat laporan penjualan, laporan transaksi serta laporan pemesanan. Dalam hal ini, pelanggan dapat mengisi form pemesanan sembako.

\section{a. Analisis Sistem Yang Sedang Berjalan}

Tahap ini merupakan tahap dilakukan penulis terhadap sistem yang sedang berjalan. Analisa ini bertujuan untuk mengenali lebih jauh sistem yang sedang digunakan. Adapun sistem yang sedang berjalan pada UD. Bintan Jaya sebagai berikut :

\section{Use Case Diagram Gambaran Umum Sistem}

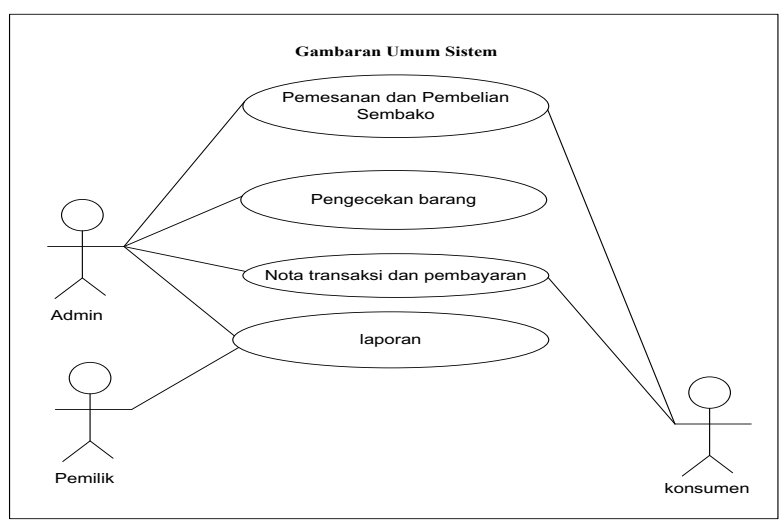

Gambar 2. Use Case Diagram Gambaran Umum Sistem

Penjelasan Use Case Diagram Gambaran Umum Sistem.

a. Konsumen memesan dan membeli sembako.

b. Kemudian admin melakukan pengecekan barang yang dipesan.

c. Setelah itu admin membuat nota transaksi dan menyerahkan ke konsumen untuk melakukan pembayaran.

d. Admin membuat laporan.

e. Setelah itu, admin menyerahkan laporan kepada pemilik toko.

2. Activity Diagram Gambaran Umum Sistem Pengisian Form Pemesanan Sembako

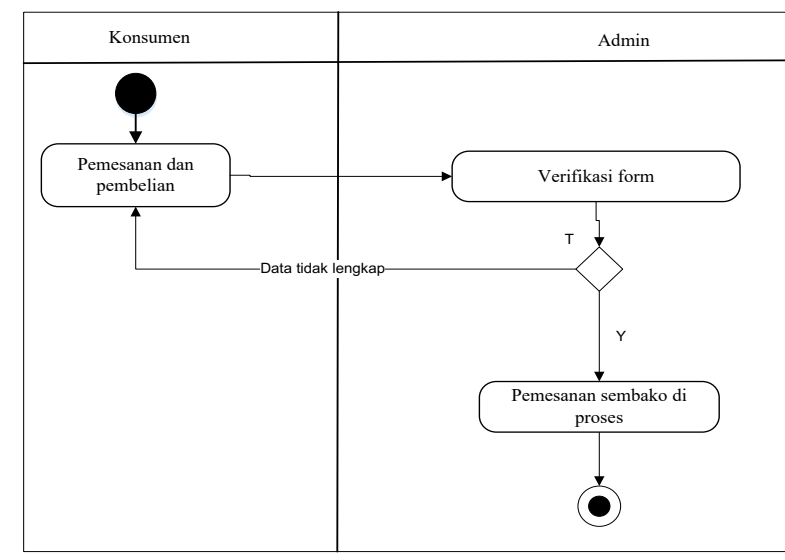

Gambar 3. Activity Diagram Pengisian Form Pemesanan Sembako

Penjelasan Activity Diagram Pemesanan Sembako.

a. Konsumen memesan dan membeli sembako.

b. Kemudian admin memverifikasi data di form.

c. Jika data tidak lengkap, maka form dikembalikan kepada pelanggan untuk dilengkap.

d. Jika form lengkap, maka admin mencatat kedalam buku pemesanan sembako. 


\section{Activity Diagram Gambaran Umum Sistem Sistem Data Transaksi dan Pembuatan Laporan}

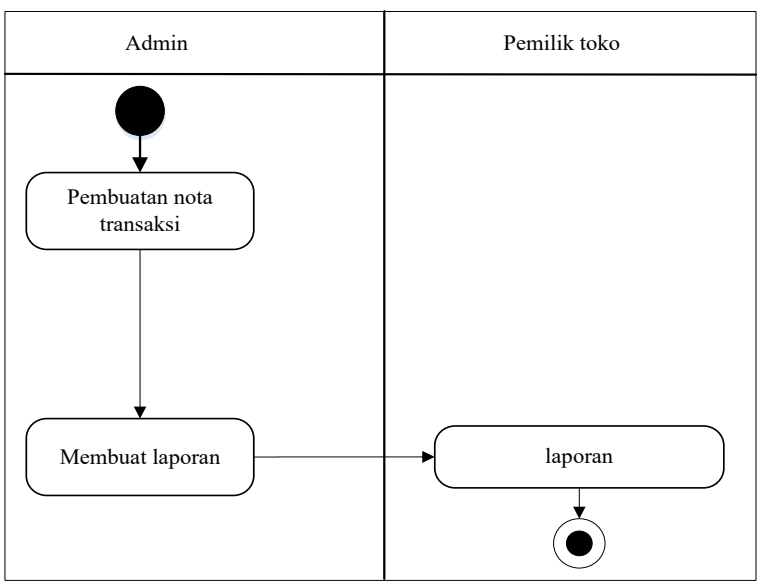

Gambar 4. Activity Diagram Data Transaksi dan Pembuatan Laporan

Penjelasan Activity Diagram Pencatatan Data

Transaksi dan Laporan.

a. Admin membuat nota transaksi.

b. Setelah itu admin juga membuat laporan.

c. Laporan tersebut diserahkan kepada pemilik toko.

\section{b. Perancangan Sistem}

Perancangan sistem adalah strategi untuk memecahkan masalah dan mengembangkan solusi terbaik bagi permasalahan itu. Perancangan sistem informasi bertujuan untuk memberikan gambaran mengenai sistem yang diusulkan sebagai penyempurnaan dari sistem yang sedang berjalan. Dari analisa penulis terhadap sistem yang sedang berjalan, diperlukan perbaikan dalam pengolahan data.

Maka penulis mengajukan suatu perancangan sistem yang nantinya diharapkan dapat meminimalisir bahkan dapat mengatasi permasalahan. Sistem yang dirancang ini menggunakan media komputer sebagai bagian dari sistem dan diaplikasikan kedalam suatu program aplikasi.

\section{Use Case Diagram Yang Diusulkan}

Use Case adalah rangkaian/uraian sekelompok yang saling terkait dan membentuk sistem secara teratur yang dilakukan atau diawasi oleh sebuah aktor. Use Case digunakan untuk membentuk tingkah-laku benda/things dalam sebuah model serta di realisasikan oleh sebuah collaboration. Umumnya Use Case digambarkan dengan sebuah elips dengan garis yang solid, biasanya mengandung nama. Use Case menggambarkan proses sistem (kebutuhan sistem dari sudut pandang user).

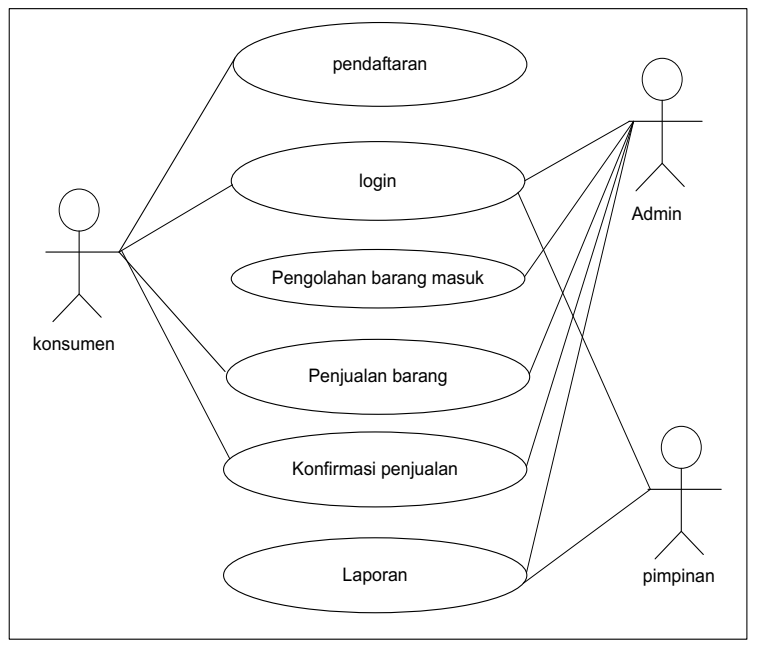

Gambar 5. Use Case Diagram

\section{Activity Diagram Yang Diusulkan}

\section{a. Activity Pendaftaran}

1. Konsumen mengunjungi website sistem informasi penjualan.

2. Sistem menampilkan halaman utama.

3. Konsumen mengeklik menu daftar.

4. Sistem menampilkan form pendaftaran.

5. Konsumen mengisi semua form yang tersedia apabila sudah maka konsumen mengeklik tombol simpan.

6. Sistem mengecek data sudah terisi dengan benar apabila sudah benar akan tersimpan ke dalam database, jika salah maka akan menampilkan pesan error.

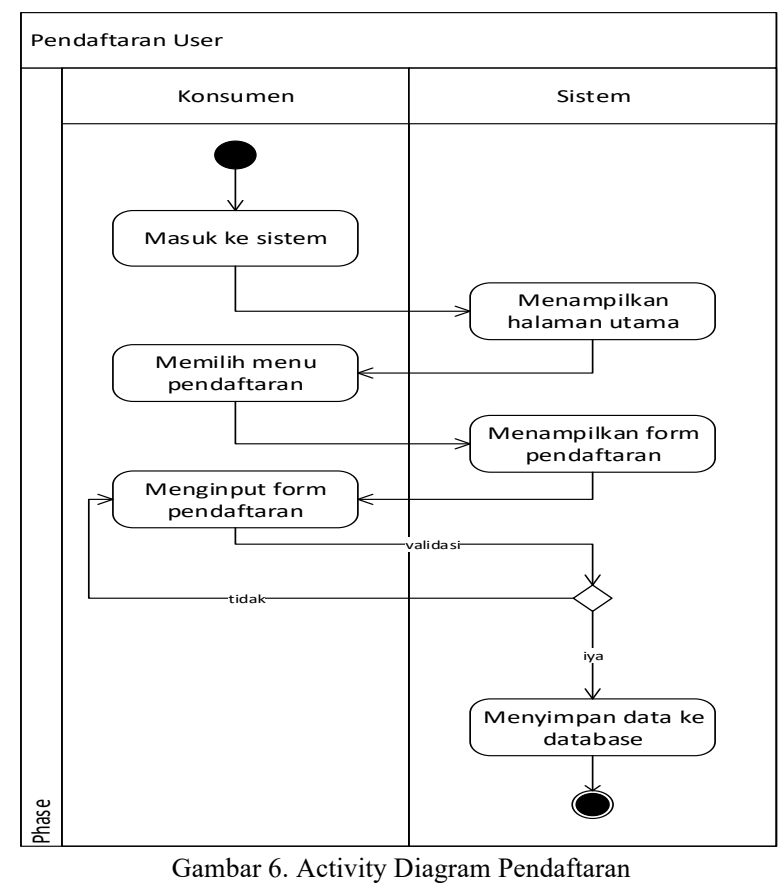

b. Activity Login

1. User membuka aplikasi dan memilih menu login.

2. Menampilkan form login.

3. Input username dan password. 
4. Apabila username dan password benar maka menampilkan halaman utama.

5. Sistem mengecek data sudah terisi dengan benar apabila sudah benar akan tersimpan ke dalam database, jika salah maka akan menampilkan pesan error.

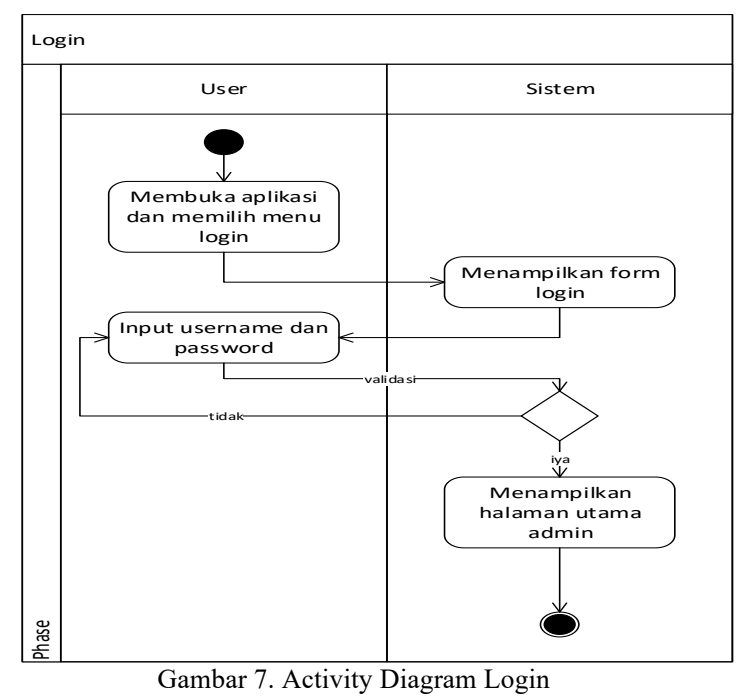

c. Activity Data Mengolah Barang Masuk

1. Admin mengeklik menu barang masuk.

2. Sistem menampilkan data barang masuk.

3. Admin mengeklik tombol tambah.

4. Setelah itu akan tampil form barang masuk.

5. Maka admin menginput form barang masuk yang tersedia apabila sudah terisi maka admin mengeklik tombol simpan.

6. Jika inputan benar maka data akan tersimpan di database, jika salah akan muncul pesan error.

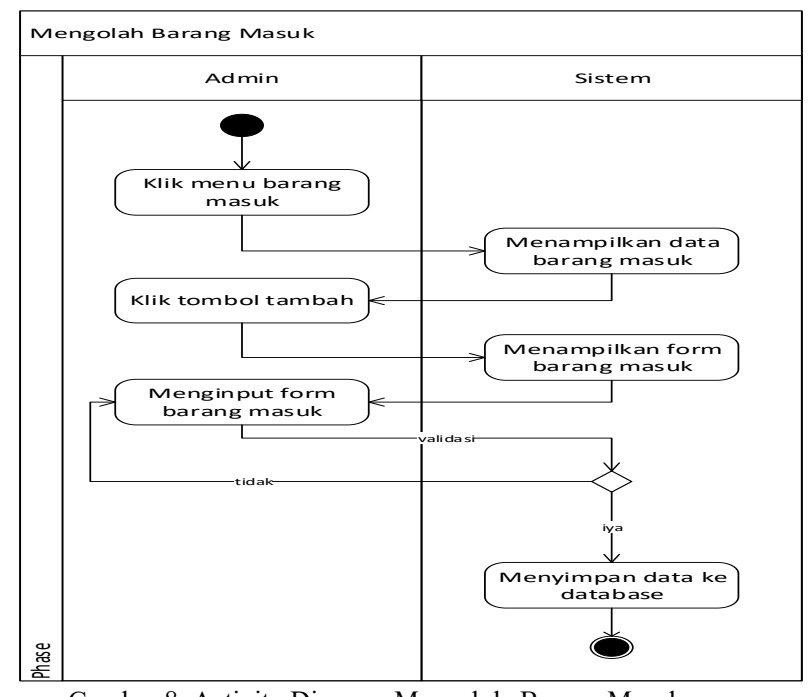

Gambar 8. Activity Diagram Mengelola Barang Masuk

\section{d. Activtiy Diagram Penjualan Barang}

1. Konsumen memilih barang yang diinginkan.

2. Sistem akan menyimpan barang yang dipilih ke dalam keranjang belanja.

3. Konsumen mengeklik menu pembayaran.
4. Sistem menampilkan rincian pembayaran dan total yang harus dibayarkan.

5. Konsumen mengeklik tombol bayar.

6. Sistem menampilkan data jumlah pembayaran dan metode pembayaran.

7. Jika konsumen sudah melakukan pembayaran maka konsumen harus mengkonfirmasi pembayarannya melalui menu konfirmasi pembayaran.

8. Sistem menampilkan form konfirmasi pembayaran.

9. Konsumen mengisi form yang tersedia apabila sudah terisi konsumen mengeklik tombol simpan.

10. Sistem menyimpan data ke dalam database.

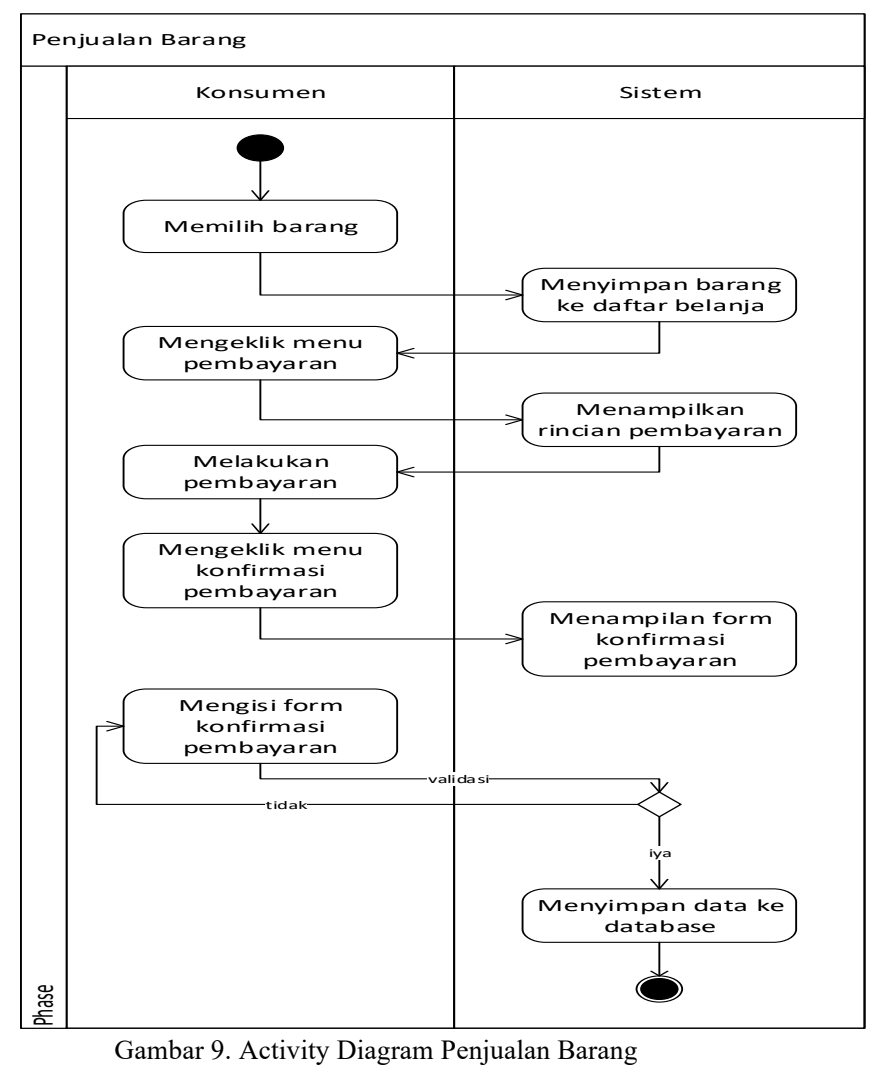

e. Activity Diagram Konfirmasi Penjualan

1. Admin mengeklik menu konfirmasi penjualan.

2. Sistem menampilkan data penjualan.

3. Admin memilih salah satu data yang akan dikonfirmasikan.

4. Sistem menampilkan form konfirmasi.

5. Apabila yang data sudah sesuai maka admin menceklis sesusai namun apabila tidak sesuai maka admin mengeklik tidak sesuai dan user harus mengisi ulang form konfirmasi pembayaran. 


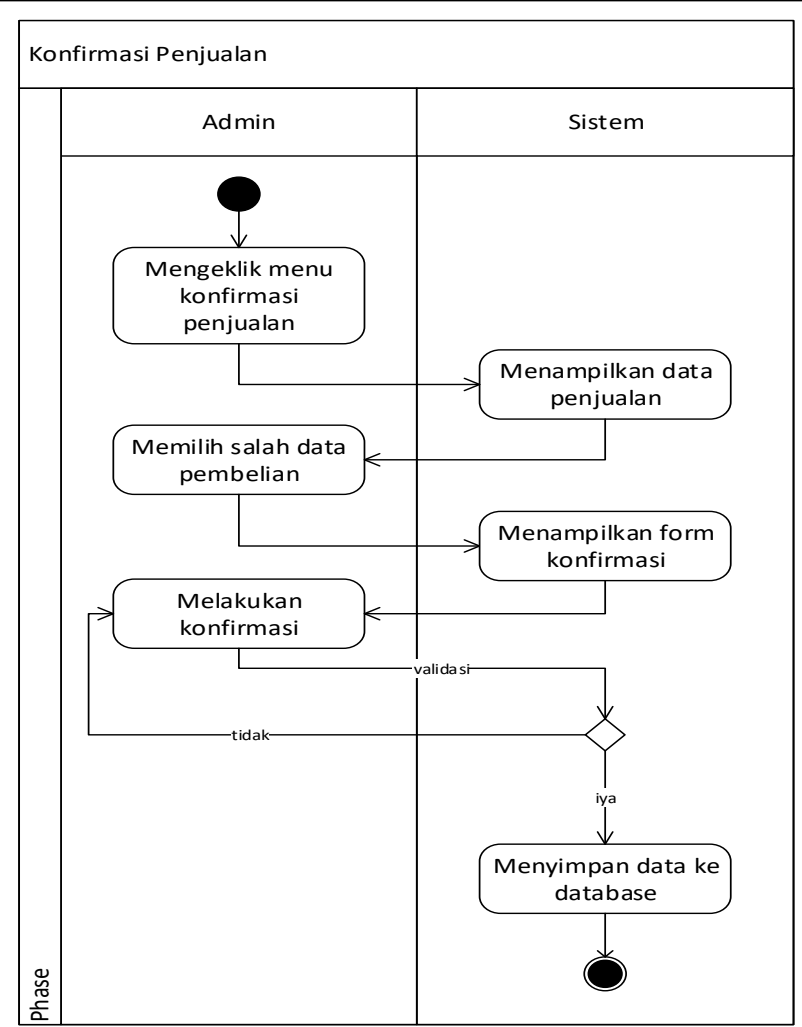

Gambar 10. Activity Diagram Konfirmasi Penjualan

\section{f. Activtity Diagram Laporan}

1. Admin mengklik menu laporan.

2. Setelah itu admin memilih laporan yang ingin dicetak.

3. Kemudian akan tampil laporan sesuai pilihan.

4. Admin mencetak laporan.

5. Laporan yang sudah dicetak diserahkan ke pemilik perusahaan.

\section{c. Implementasi Sistem}

Sistem setelah dianalisa dan dirancang, maka sistem tersebut siap diterapkan atau diimplementasikan. Tahap implementasi sistem ini merupakan tahap meletakkan perancangan sistem kedalam bentuk coding bahasa pemrograman selain implementasi dalam instansi atau perusahaan dan dioperasikan sesegera mungkin.

Dalam rencana implementasi sistem ada empat landasan yang akan dikemukakan, yaitu :

1. Untuk mengkaji mengenai rangkaian sistem, baik software maupun hardware dalam bentuk sistem informasi terpusat (integrated information system).

2. Untuk melakukan uji coba mengenai perangkat lunak sistem (software) maupun perangkat keras (hardware) sebagai sarana pengolah data dan sekaligus penyaji informasi yang dibutuhkan.

3. Untuk melakukan penerapan serta peralihan sistem yang lama ke sistem yang baru.

\section{d. Kegiatan Implementasi}

Kegiatan implementasi ini antara lain :

1. Pemrograman

Pemrograman merupakan kegiatan yang sangat menunjang terselenggaranya sistem yang baru karena program yang baik dan struktur dapat menghasilkan suatu informasi sesuai kebutuhan. Sebelum program diterapkan maka program harus diuji coba dulu agar dapat meminimalkan kesalahan-kesalahan yang mungkin terjadi. Pengujian program dapat dilakukan untuk setiap modul program (Program Utama, Sub Rutin, Sub Program) yang dilanjutkan dengan pengujian semua modul untuk meyakinkan semua modul sudah terintegrasi tanpa kesalahan.

2. Pengujian Aplikasi

Pengujian aplikasi ini dilakukan untuk memeriksa kekompakan antar komponen aplikasi dengan tujuan utamanya adalah untuk memastikan elemen-elemen aplikasi berfungsi sesuai dengan yang diharapkan.

3. Pengujian Sistem

Pengujian sistem yang dilakukan untuk memeriksa kekompakan antar komponen sistem, dengan tujuan utamanya adalah untuk memastikan elemen-elemen sistem yang berfungsi sesuai dengan yang diharapkan. Pengujian sistem termasuk juga pengujian program secara menyeluruh. Kumpulan program dapat menerima dengan baik, memproses dan memberikan hasil keluaran program yang baik juga.

TABEL I

PelaksanaAn PENGUJian Black Box

\begin{tabular}{|c|c|c|c|}
\hline $\begin{array}{l}\text { Modul yag } \\
\text { diuji }\end{array}$ & $\begin{array}{c}\text { Proses } \\
\text { Pengujian }\end{array}$ & $\begin{array}{l}\text { Hasil yg } \\
\text { Dicapai }\end{array}$ & $\begin{array}{c}\text { Hasil yg } \\
\text { Diharap } \\
\text { kan }\end{array}$ \\
\hline Login & $\begin{array}{l}\text { Admin pilih } \\
\text { login dengan } \\
\text { memasukan } \\
\text { username dan } \\
\text { password }\end{array}$ & $\begin{array}{l}\text { Menampilka } \\
\mathrm{n} \text { halaman } \\
\text { utama }\end{array}$ & $\begin{array}{l}\text { Data } \\
\text { login } \\
\text { tersimpan } \\
\text { dalam } \\
\text { database }\end{array}$ \\
\hline $\begin{array}{l}\text { Edit profil } \\
\text { admin }\end{array}$ & $\begin{array}{l}\text { Pilih edit } \\
\text { profi, dan } \\
\text { admin dapat } \\
\text { mengbah data } \\
\text { sesuai } \\
\text { keinginan }\end{array}$ & $\begin{array}{l}\text { Data yang } \\
\text { sudah } \\
\text { diubah akan } \\
\text { muncul } \\
\text { secara } \\
\text { otomatis }\end{array}$ & $\begin{array}{l}\text { Data } \\
\text { yang } \\
\text { diubah } \\
\text { tersimpan } \\
\text { dalam } \\
\text { database }\end{array}$ \\
\hline $\begin{array}{l}\text { Tambah } \\
\text { data } \\
\text { barang } \\
\text { masuk }\end{array}$ & $\begin{array}{l}\text { Input data } \\
\text { barang }\end{array}$ & $\begin{array}{l}\text { Data akan } \\
\text { muncul }\end{array}$ & $\begin{array}{l}\text { Data } \\
\text { yang } \\
\text { diinput } \\
\text { akan } \\
\text { muncul } \\
\text { dan } \\
\text { tersimpan }\end{array}$ \\
\hline $\begin{array}{l}\text { Data } \\
\text { penjualan }\end{array}$ & $\begin{array}{l}\text { Klik Data } \\
\text { penjualan }\end{array}$ & $\begin{array}{l}\text { Data akan } \\
\text { muncul }\end{array}$ & $\begin{array}{l}\text { Data } \\
\text { yang } \\
\text { sudah } \\
\text { terinput } \\
\text { akan } \\
\text { muncul }\end{array}$ \\
\hline Hapus data & $\begin{array}{l}\text { Pilih data yang } \\
\text { akan dihapus }\end{array}$ & $\begin{array}{l}\text { Data yang } \\
\text { dihapus akan } \\
\text { hilang secara } \\
\text { otomatis }\end{array}$ & $\begin{array}{l}\text { Data } \\
\text { terhapus }\end{array}$ \\
\hline $\begin{array}{l}\text { Pencarian } \\
\text { data }\end{array}$ & $\begin{array}{l}\text { Pilih kolom } \\
\text { pencarian, dan } \\
\text { masukan kode }\end{array}$ & $\begin{array}{l}\text { Hasi yang } \\
\text { dicari akan } \\
\text { muncul } \\
\end{array}$ & $\begin{array}{l}\text { Hasil } \\
\text { pencarian } \\
\text { akan }\end{array}$ \\
\hline
\end{tabular}




\begin{tabular}{|c|c|c|c|}
\hline & & & $\begin{array}{l}\text { muncul } \\
\text { secara } \\
\text { otomatis }\end{array}$ \\
\hline $\begin{array}{l}\text { Form Ubah } \\
\text { Password }\end{array}$ & $\begin{array}{l}\text { Ubah } \\
\text { Password } \\
\text { sesuai } \\
\text { keinginan }\end{array}$ & $\begin{array}{l}\text { data } \\
\text { password } \\
\text { yang diubah } \\
\text { bisa } \\
\text { digunakan }\end{array}$ & $\begin{array}{l}\text { Password } \\
\text { tersimpan }\end{array}$ \\
\hline $\begin{array}{l}\text { Detail } \\
\text { produk }\end{array}$ & $\begin{array}{l}\text { Klik detail } \\
\text { produk }\end{array}$ & $\begin{array}{l}\text { Produk yang } \\
\text { dipilih akan } \\
\text { tampil }\end{array}$ & $\begin{array}{l}\text { Data } \\
\text { produk } \\
\text { yang } \\
\text { dipilih } \\
\text { akan } \\
\text { muncul } \\
\end{array}$ \\
\hline $\begin{array}{l}\text { Form } \\
\text { barang }\end{array}$ & $\begin{array}{l}\text { Input form } \\
\text { barang }\end{array}$ & $\begin{array}{l}\text { Data yang } \\
\text { diinput akan } \\
\text { muncul }\end{array}$ & $\begin{array}{l}\text { Data } \\
\text { yang } \\
\text { diinput } \\
\text { akan } \\
\text { tersimpan } \\
\text { secara } \\
\text { otomatis }\end{array}$ \\
\hline Histori & $\begin{array}{l}\text { Klik histori } \\
\text { pembelian }\end{array}$ & $\begin{array}{l}\text { Data } \\
\text { pembelian } \\
\text { akan muncul }\end{array}$ & $\begin{array}{l}\text { Data } \\
\text { yang } \\
\text { dipilih } \\
\text { akan } \\
\text { muncul }\end{array}$ \\
\hline Kategori & $\begin{array}{l}\text { Pilih kategori } \\
\text { barang }\end{array}$ & $\begin{array}{l}\text { Data barang } \\
\text { akan muncul }\end{array}$ & $\begin{array}{l}\text { Data } \\
\text { yang } \\
\text { dipilih } \\
\text { akan } \\
\text { muncul } \\
\text { sesuai } \\
\text { kategori }\end{array}$ \\
\hline Keranjang & Klik keranjang & $\begin{array}{l}\text { Maka data } \\
\text { barang di } \\
\text { keranjang } \\
\text { akan muncul }\end{array}$ & $\begin{array}{l}\text { Data } \\
\text { dalam } \\
\text { keranjang } \\
\text { akan } \\
\text { muncul } \\
\text { dan dapat } \\
\text { menamba } \\
\text { h barang } \\
\text { lagi }\end{array}$ \\
\hline $\begin{array}{l}\text { Konfirmasi } \\
\text { pembelian }\end{array}$ & $\begin{array}{l}\text { Klik } \\
\text { konfirmasi }\end{array}$ & $\begin{array}{l}\text { Data } \\
\text { pembelian } \\
\text { akan } \\
\text { dikonfirmasi }\end{array}$ & $\begin{array}{l}\text { Data } \\
\text { pembelia } \\
\mathrm{n} \text { akan } \\
\text { terkonfir } \\
\text { masi dan } \\
\text { tersimpan }\end{array}$ \\
\hline $\begin{array}{l}\text { Laporan } \\
\text { barang }\end{array}$ & $\begin{array}{l}\text { Klik laporan } \\
\text { barang }\end{array}$ & $\begin{array}{l}\text { Data barang } \\
\text { di laporan } \\
\text { akan mucul }\end{array}$ & $\begin{array}{l}\text { Data } \\
\text { laporan } \\
\text { muncul } \\
\text { sesuai } \\
\text { yang } \\
\text { diinginka } \\
\mathrm{n}\end{array}$ \\
\hline
\end{tabular}

\section{KESIMPULAN}

Berdasarkan hasil proses perancangan dan pembuatan Sistem Informasi Penjualan Berbasis Web pada UD. Bintan Jaya penulis menyimpulkan bahwa :

1. Dengan adanya aplikasi ini maka dapat meminimalisir waktu transaksi pembelian.

2. Dengan adanya aplikasi ini maka dapat memudahkan konsumen dalam melakukan pembayaran barang.

3. Dengan adanya aplikasi ini maka penyimpanan data laporan menjadi efektif dan rapih.

4. Dengan adanya aplikasi ini maka dapat memudahkan penjual dalam mengisi data barang yang akan dijual.

5. Dengan adanya aplikasi ini dapat memudahkan penjual melakukan rekapan data penjualan dan dapat meminimalisir waktu pembuatan.

6. Dengan adanya aplikasi ini dapat memudahkan pembeli dalam melakukan melakukan pembelian tanpa harus datang ke toko.

7. Dengan adanya aplikasi ini, konsumen dapat mengetahui secara langsung harga barang yang akan dibeli.

8. Dengan adanya aplikasi ini penjual lebih mudah dalam pembuatan data transaksi.

\section{UCAPAN TERIMA KASIH}

Segala puji dan syukur penyusun panjatkan pada TuhanYang Maha Esa, Karena berkat dan rahmat-Nya akhirnya penyusun dapat menyelesaikan Skripsi ini untuk melengkapi salah satu syarat dalam kelulusan Program Strata 1 di Sekolah Tinggi Teknologi Indonesia Tanjungpinang.

Penyusun sadar akan keterbatasan dalam penulisan skripsi ini, maka kritik dan saran yang membangun dari semua pihak sangatlah berarti bagi penyusun untuk dapat melakukan perbaikan yang lebih mendekati sempurna. Selesainya skripsi ini tidak lepas dari bantuan berbagai pihak yang telah mendorong dan membimbing penyusun, baik tenaga, ide-ide, maupun pemikiran. Oleh karena itu dalam kesempatan ini penyusun ingin mengucapkan terimakasih yang sebesarbesarnya kepada :

1. Wanhendra, M.SI selaku Dosen Pembimbing atas segala curahan waktu dan pemikiraannya dalam proses penyelesaian skripsi ini.

2. Bapak H.M. Lois Frederik, SE., SH., MM selaku Ketua STT Indonesia Tanjungpinang atas segala kesempatan kepada penyusun dalam menjalani pendidikan tinggi di Sekolah Tinggi Teknologi Indonesia Tanjungpinang.

3. Ibu Dwi Nurul Huda, S.T., M.Kom selaku Ketua Jurusan Sistem Informasi atas segala arahan dan tuntunan dalam proses penyelesaian masa studi yang penyusun lakukan.

4. Segenap manajemen UD. Bintan Jaya yang telah memberikan izin bagi penulis untuk mengadakan penelitian.

5. Terutama ku persembahkan Skripsi ini sebagai tanda baktiku kepada kedua orang tuaku tercinta Ayahanda HERMAN dan Ibunda LILY. Terimakasihku atas cinta, kasih sayang, nasehat dan doa yang tiada henti-hentinya sehingga penulis dapat menyelesaikan perkuliahan dan kerja praktek ini dengan baik. 


\section{REFERENSI}

[1] Alan Nur Aditya, Jago PHP \& MySQL,: DUNIA KOMPUTER, 2011, Bekasi - Jawa Barat

[2] A.S Rosa dan M Salahuddin, Rekayasa Perangkat Lunak terstruktur dan berorientasi objek, Informatika, 2014, Bandung

[3] J Asropudin, Pipin, Kamus Teknologi Informasi Komunikasi, Titian Ilmu, 2013, Bandung.

[4] Chaniago, Arifinal, Ekonomi dan Koperasi, CV. Rosda Bandung, 2001, Bandung

[5] Gregorius, Agung, MySQL untuk pemula, PT Elek media Komputindo Kelompok Gramedia, 2014, Jakarta

[6] M.Dimas T.S., Pembuatan Aplikasi Game Dark Side of the Moon, 2015, Bandung

[7] Masrul Nur, Aplikasi Penerapan Teknologi Augmented Reality Untuk Penanganan Penderita Stroke Berbasis Android Naskah Publikasi
[8] M. Rhandy Kahfi. Sistem Informasi Pada Point Of Sales Berbasis Android Barcode Scanner [ Skripsi, 2016].

[9] Mulyanto Agung, Sistem Informasi Konsep dan Aplikasi, Pustaka Belajar, 2009, Yogyakarta

[10] Nugroho, mengenal XAMPP awal, 2013, MediaKom, Yogyakarta

[11] Panduan KP dan TA STT INDONESIA TANJUNGPINANG, 2014, Tanjungpinang.

[12] Purnomo Herry, Zacharias Theo, Pengenalan Informatika Perpektif Teknik dan Lingkungan, Penerbit ANDI, 2005, Jakarta

[13] Pressman, R.S. Rekayasa Perangkat Lunak, Pendekatan Praktisi Buku I, 2015, Yogyakarta

[14] Verdi Yasin, Rekayasa Perangkat Lunak Berorientasi objek, Mitra Wacana Media, 2012, jakarta

[15] Y, Sugiarti, Analisis dan Perancangan UML (Unified Modeling Language), Graha Ilmu, 2013, Yogyakarta 